\title{
JAMU HERBAL UNTUK MENINGKATKAN IMUNITAS TUBUH DI MASA PANDEMI COVID-19
}

\author{
Zainal Abidin*, Novi Indriani \\ Fakultas Keguruan dan Ilmu Pendidikan, Universitas Islam Malang \\ *korespondensi email: zainal_abid@unisma.ac.id
}

\begin{abstract}
ABSTRAK
Tanaman obat tidak hanya bermanfaat sebagai bumbu penyedap masakan, bahan makanan ataupun sebagai hiasan. Tanaman obat juga bermanfaat menjaga dan meningkatkan imunitas tubuh. Tanaman obat dibuat dalam bentuk jamu herbal dapat digunakan untuk meningkatkan imunitas tubuh di masa pandemi covid-19. Pengabdian Masyarakat melalui kegiatan dengan upaya meningkatkan imunitas tubuh dengan jamu herbal dilaksanakan di Desa Pujiharjo, Kecamatan Tirtoyudo, Kabupaten Malang. Metode pengabdian yang digunakan yaitu tahap pertama melakukan sosialiasasi kepada warga dan tahap kedua melayani masyarakat dalam meningkatkan imunitas tubuh. Hasil dari kegiatan pengabdian masyarakat ini adalah: 1) sasyarakat lebih menghargai terhadap imunitas tubuhnya, 2) warga mengetahui pentingnya imunitas tubuh, 3) warga mengetahui jamu herbal dapat meningkatkan imunitas tubuh.
\end{abstract}

Kata Kunci: jamu herbal; imunitas tubuh; covid-19; desa pujiharjo

\section{PENDAHULUAN}

Indonesia adalah negara kaya akan keanekaragaman tanaman obatnya. Lebih dari 1000 spesies tumbuhan dapat dimanfaatkan sebagai bahan baku pembuatan obat (Karamina et al., 2020). Budidaya tanaman obat negara Indonesia memiliki potensi yang sangat baik. Sehingga negara Indonesia menempati posisi terbesar kedua setelah negara Brazil (Margarethy et al., 2019; Wahidah, 2013). Tanaman tidak hanya bermanfaat sebagai bumbu penyedap masakan, bahan makanan ataupun sebagai hiasan. Tanaman juga bermanfaat menjaga dan meningkatkan imunitas tubuh (Nurlila \& La Fua, 2020; Pertiwi et al., 2020).

Imunitas adalah sistem kekebalan tubuh manusia untuk menangkal segala macam penyakit yang masuk dalam tubuh manusia (Gumantan et al., 2020). Banyak faktor yang menyebabkan imunitas tubuh manusia menurun, salah satunya adalah kelelahan bekerja. Kelelahan mungkin dianggap hal biasa, tapi pada dasarnya kondisi yang diawali dengan menurunya daya tahan tubuh ini dapat memicu berbagai penyakit. Agar tetap sehat dan terhindar dari infeksi virus covid-19 pada masa pandemi ini, imunitas tubuh harus dijaga, salah satunya dengan mengkonsumsi jamu atau ramuan herbal (Alam, 2020; Zayadi et al., 2016). Jamu herbal sendiri identik dengan masyarakat perdesaan, sebab pengembangan tanaman obat memiliki tingkat efektivitas yang cukup tinggi apabila dikelola dan dilaksanakan pada area desa (Martino et al., 2018). Desa baik secara antropologi dan topografi memiliki tingkat lahan terbuka yang cukup tinggi dibandingkan dengan daerah perkotaan (Suparmini \& Wijayanti, 2015). 
Desa Pujiharjo adalah sebuah desa yang berada di wilayah Kecamatan Tirtoyudo, Kabupaten Malang. Desa Pujiharjo cukup jauh dari pusat Kota Malang, jarak tempuh sekitar $80 \mathrm{Km}$, yang dapat ditempuh dengan waktu sekitar 3 jam. Desa Pujiharjo memiliki luas wilayah 5.530 Ha. Secara administratif, Desa Pujiharjo terletak di wilayah desa-desa tetangga yaitu: sebelah utara berbatasan dengan Desa Sumber Tangkil Kecamatan Tirtoyudo, sebelah barat berbatasan dengan Desa Purwodadi Kecamatan Tirtoyudo, sebelah selatan berbatasan dengan samudra Indonesia, sebelah timur berbatasan dangan Desa Lebakharjo Kecamatan Ampelgading.

Mayoritas mata pencaharian penduduk Desa Pujiharjo teridentifikasi di sektor pertanian. Sebagian lainnya teridentifikasi ke dalam sektor nelayan, wirausahawan, pegawai swasta, dan pegawai negeri sipil. Kondisi saat ini, masyarakat di Desa Pujiharjo belum sepenuhnya memahami bahwa jamu herbal dapat meningkatkan imunitas tubuh. Pengetahuan masyarakat untuk meminum jamu herbal merupakan pengetahuan dan pengalaman atau hanya kebiasan yang diwariskan secara turun temurun oleh nenek moyang.

Jamu herbal atau obat tradisional adalah ramuan yang berasal dari tumbuhantumbuhan yang berkhasiat (Wadjdi et al., 2020). Masyarakat memanfaatkan jamu herbal biasanya untuk mencegah, menyembuhkan, dan mengobati penyakit. Beralihnya masyarakat ke obat tradisional atau jamu herbal karena harga lebih murah, bahan lebih mudah didapatkan bila ditanam sendiri dan umumnya satu tanaman memiliki efek farmakologi lebih dari satu sehingga bermanfaat untuk pengobatan penyakit degeneratif dan metabolic (Ningsih, 2016). Sudah umum diketahui bahwa jamu herbal lebih aman karena bersifat alami dan memiliki efek samping lebih sedikit dibandingkan obat-obatan pabrik atau kimia. Dari uraian tersebut, maka tujuan dari pengabdian ini adalah untuk memberi pengetahuan mengenai manfaat jamu herbal dalam meningkatkan imunitas tubuh di tengah masa pandemi Covid-19 serta bertujuan sebagai upaya meningkatan kesehatan masyarakat melalui jamu herbal yang bersinergi dengan Jamu Herbal Sido Waras Blok. 9.

\section{METODE}

Pengabdian ini dilaksanakan pada bulan Februari 2021 selama 1 bulan yang bertempat di Desa Pujiharjo, khususnya Dusun Krajan Blok. 9 RT: 08 RW: 02. Pengabdian ini dilakukan dengan bimbingan satu dosen dan mahasiswa KSM (Kandidat Sarjana Mengabdi)Tematik Edisi Covid-19 Kelompok 56 Tahun Akademik 2020/2021 berdomisili Desa Pujiharjo. Metode pengabdian yang digunakan yaitu dengan melakukan sosialiasasi kepada warga terlebih dahulu, selanjutnya masuk ke tahap pelayanan dalam meningkatkan imunitas tubuh masyarakat.

Tabel 1. Rincian kegiatan pengabdian

\begin{tabular}{|c|c|c|c|}
\hline Metode Pengabdian & Kegiatan & Tujuan & Output \\
\hline $\begin{array}{l}\text { Sosialilasi manfaat dan } \\
\text { lokasi jamu herbal }\end{array}$ & $\begin{array}{l}\text { Menyelenggarakan } \\
\text { sosialisasi mengenai } \\
\text { manfaat yang bisa } \\
\text { didapatkan dari jamu } \\
\text { herbal dan menjelaskan } \\
\text { lokasi jamu herbal di } \\
\text { Desa Pujiharjo Blok. } 9 \\
\text { RT. 08 RW. } 02 \\
\text { Melakukan pelayan }\end{array}$ & $\begin{array}{l}\text { Tujuan dari kegiatan } \\
\text { meningkatkan imunitas tubuh } \\
\text { masyarakat di masa pandemi } \\
\text { covid-19 adalah 1) masyarakat } \\
\text { lebih menghargai terhadap } \\
\text { imunitas tubuhnya, 2) masyarakat } \\
\text { mengetahui pentingnya imunitas } \\
\text { tubuh, 3) masyarakat mengetahui } \\
\text { jamu herbal dapat meningkatkan }\end{array}$ & $\begin{array}{l}\text { 1) Diharapkan masyarakat } \\
\text { lebih menghargai terhadap } \\
\text { imunitas tubuhnya, 2) } \\
\text { Diharapkan masyarakat } \\
\text { mengetahui pentingnya } \\
\text { imunitas tubuh } \\
\text { 3) Diharapkan masyarakat } \\
\text { mengetahui jamu herbal } \\
\text { dapat meningkatkan }\end{array}$ \\
\hline $\begin{array}{l}\text { Pelayanan terhadap } \\
\text { masyarakat dalam } \\
\text { meningkatkan imunitas } \\
\text { tubuh }\end{array}$ & $\begin{array}{l}\text { kepada masyarakat } \\
\text { dalam meningkatkan } \\
\text { imunitas tubuh }\end{array}$ & imunitas tubuh & imunitas tubuh \\
\hline
\end{tabular}




\section{HASIL DAN PEMBAHASAN}

Sosialisasi mengenai manfaat dan lokasi jamu herbal serta pelayanan terhadap masyarakat dalam meningkatkan imunitas tubuh dilakukan di Desa Pujiharjo Blok. 9 RT 08 RW 02. Adapun rincian dari kegiatan tersebut dapat dijelaskan sebagai berikut:

\section{Sosialilasi manfaat dan lokasi jamu herbal}

Jamu adalah istilah untuk obat tradisional dari Indonesia, akhir-akhir ini populer dengan istilah herba atau herbal. Jamu herbal adalah ramuan yang dibuat dari bahan alami yang berkhasiat berupa bagian dari tumbuhan seperti akar-akaran, kulit batang, daun-daunan, dan buah. Jamu herbal juga ada yang menggunakan bahan dari tubuh hewan, seperti empedu kambing dan lain-lainnya. Komposisi dari jamu herbal dibuat dalam kegiatan ini antara lain sambiloto, jahe, kumis kucing, lempuyang, dan kayu manis.

Mengenai khasiat jamu, khasiat jamu telah teruji oleh waktu, zaman dan sejarah, serta bukti empiris langsung pada manusia selama ratusan tahun. Khasiat dari jamu herbal sendiri salah satunya adalah membantu mempertahankan imunitas, pereda nyeri dan penambah nafsu makan. Hal ini didukung oleh pendapat Dokter Raymond (dalam Sulaiman, 2016) yang menyatakan bahwa herbal berbentuk jamu memiliki sifat preventif dan promotif, dalam artian jamu menjaga seseorang dari penyakit. Jamu herbal yang digunakan dalam kegiatan ini didapat dari kulakan pada distributor cabang Desa Krebet Kecamatan Bululawang yang bekerjasama dengan CV. Putri Sejati BanyuwangiJawa Timur.

Sosialisai mengenai manfaat dan lokasi jamu herbal dilakukan di rumah-rumah warga Desa Pujiharjo. Persiapan yang dilakukan untuk mensosialisasikan mengenai manfaat dan lokasi jamu herbal berupa pembuatan dan penyebaran brosur, serta penyiapan materi untuk melakukan sosialisasi. Pada acara sosialisasi ini menjelaskan beberapa manfaat yang didapatkan dari jamu herbal.

Adapun waktu yang dibutuhkan untuk melakukan sosialisasi kepada masyarakat Desa Pujiharjo yakni selama 2 hari. Jangka waktu yang dibutuhkan cukup pendek karena peserta KSM-Tematik UNISMA Kelompok 56 domisili Desa Pujiharjo di bantu oleh teman-teman dan keluarga. Sosialisasi dilakukan dari rumah ke rumah, hal tersebut dilakukan karena untuk menghindari kerumunan dimasa pandemi Covid-19. Pensosialisasian dilakukan secara singkat karena jumlah rumah warga yang tidak sedikit, pensosialisasian diperdalam ketika warga datang ke posko KSM saat melakukan peningkatkan imunitas tubuhnya.

\section{Pelayanan terhadap masyarakat untuk meningkatkan imunitas tubuhnya}

Kegiatan memulai melayani masyarakat Desa Pujiharjo dalam meningkatkan imunitas tubuhnya pada tanggal 1 Februari 2021. Dalam proses melayani warga dalam meningkatkan imunitas tubunya, terlebih dahulu warga menyampaikan keluhan yang dirasakan sehingga bisa diketahui apa penyebab dari menurunnya imunitas tubuhnya, kemudian diberi jamu herbal sesuai apa yang dikeluhkan warga yang datang ke posko KSM pada saat itu serta memberi saran untuk mempercepat pemulihan kesehatannya dan meningkatkan imunitas tubuh warga yang bersangkutan. Cara penggunaan dari jamu herbal ini adalah kocok atau aduk terlebih dahulu sebelum diminum dan diminum 1 kali sehari 1 gelas.

Kegiatan pelayanan terhadap masyarakat dalam meningkatkan imunitas tubuh dimulai dari pukul 16.30 WIB - 21.00 WIB. Bentuk jamu herbal yang diberikan berupa jamu herbal sulingan. Untuk meningkatkan imunitas tubuh, di posko KSM ada 2 jenis, pertama berupa jamu herbal sulingan itu sendiri, yang kedua adalah berupa toga instan. 
Jamu herbal dapat dibungkus dan diminum di tempat langsung yakni posko KSM. Jamu herbal dapat di request dengan menambah telor ayam kampong, dan menambah madu sebagai pemanis agar rasanya lebih dapat diterima peminumnya.

Gambar kerja proses pelayanan terhadap masyarakat dalam meningkatkan imunitas tubuh dan aktivitas mahasiswa KSM/KKN Kelompok 56 Universitas Islam Malang domisili Desa Pujiharjo. Terlihat pada gambar 1 dan 2.

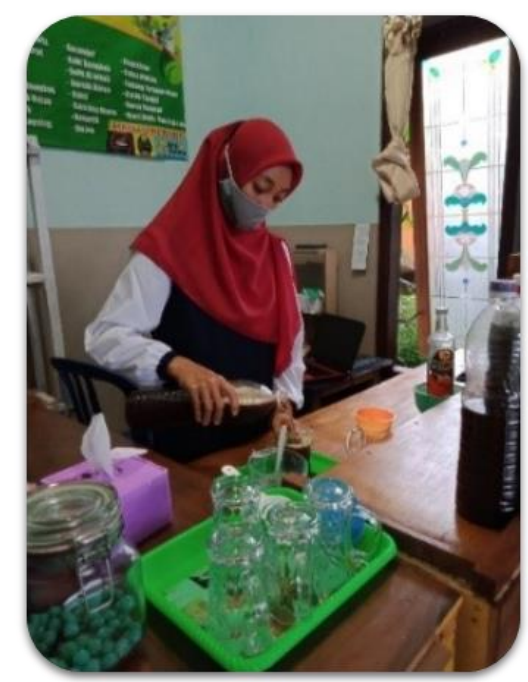

Gambar 1. Proses pembuatan atau meracik jamu herbal sulingan

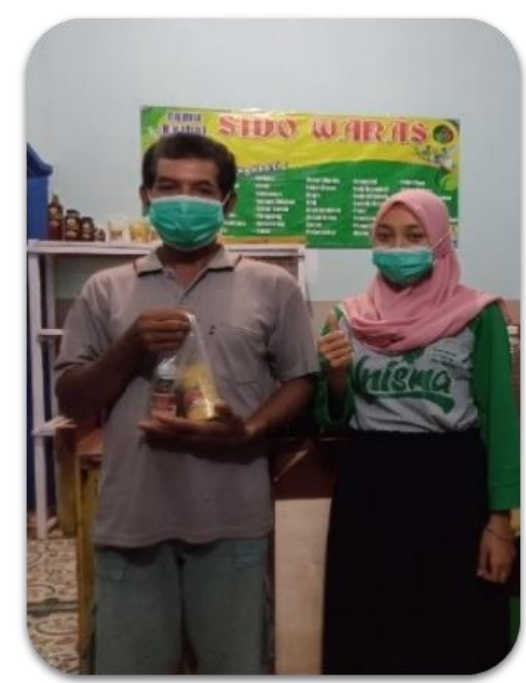

Gambar 2. Warga meningkatkan imunitas tubuh dengan jenis toga instan

\section{KESIMPULAN}

Jamu herbal sangat bermanfaat bagi masyarakat Indonesia khususnya Desa Pujiharjo Kecamatan Tirtoyudo. Mengingat saat ini masih dalam masa pandemi covid-19, maka menjaga imunitas tubuh sangat penting. Kondiisi saat ini selaras dengan slogan yang berbunyi "lebih baik mencegah daripada mengobati". Jadi di masa pandemi Covid-19 ini selalu jaga diri, jaga keluarga, jaga negara agar terhindar dari virus corona.

Dari kegiatan-kegiatan tersebut dampak yang didapatkan masyarakat Desa Pujiharjo adalah mendapatkan pengetahuan bahwa menghargai imunitas tubuh itu penting, dan masyarakat Desa Pujiharjo mengetahui bahwa jamu herbal dapat meningkatkan imunitas 
tubuh. Selain itu yang terpenting adalah jaga imunitas tubuh tetap stabil agar tehindar dari virus corona dan pemicu berbagai macam penyakit.

\section{DAFTAR RUJUKAN}

Alam, S. O. (2020). Panduan Meracik Jamu Herbal dari BPOM untuk Tingkatkan Imunitas. DetikHealth. https://health.detik.com/berita-detikhealth/d-5033858/panduanmeracik-jamu-herbal-dari-bpom-untuk-tingkatkan-imunitas

Gumantan, A., Mahfud, I., \& Yuliandra, R. (2020). Tingkat Kecemasan Seseorang Terhadap Pemberlakuan New Normal Dan Pengetahuan Terhadap Imunitas Tubuh. Sport Science and Education Journal, 1(2), 18-27. https://doi.org/10.33365/ssej.v1i2.718

Karamina, H., Supriyadi, S., Firman Yasin, D. D., Yusi Kamhar, M., \& Kusuma Astuti, F. (2020). Pemanfaatan dan Penanaman Tanaman Obat Keluarga (TOGA) Menuju Keluarga Sehat Pada Ibu Pemberdayaan Kesejahteraan Keluarga (PKK). Jurnal Inovasi Hasil Pengabdian Masyarakat (JIPEMAS), 3(2), 120-127. https://doi.org/10.33474/jipemas.v3i2.6416

Margarethy, I., Yahya, \& Salim, M. (2019). Kearifan lokal dalam pemanfaatan tumbuhan untuk mengatasi malaria oleh pengobat tradisional di Sumatera Selatan. Journal of Health Epidemiology and Communicable Diseases, 5(2), 40-48. https://doi.org/10.22435/jhecds.v5i2.2088

Martino, Y. A., Sulistiowati, E., \& Purnomo, Y. (2018). Model Pemberdayaan Santri Ponpes AlHidayah Batu Alang Sebagai Kader Kesehatan Berbasis Terapi Herbal. Jurnal Inovasi Hasil Pengabdian Masyarakat (JIPEMAS), 1(2), 86-93. https://doi.org/10.33474/jipemas.v1i2.1514

Ningsih, I. Y. (2016). Studi Etnofarmasi Penggunaan Tumbuhan Obat Oleh Suku Tengger Di Kabupaten Lumajang Dan Malang, Jawa Timur. PHARMACY: Jurnal Farmasi Indonesia (Pharmaceutical Journal of Indonesia), 13(01), 10-20. http://jurnalnasional.ump.ac.id/index.php/PHARMACY/article/view/885

Nurlila, R. U., \& La Fua, J. (2020). Jahe Peningkat Sistem Imun Tubuh di Era Pandemi Covid19 di Kelurahan Kadia Kota Kendari. Jurnal Mandala Pengabdian Masyarakat, 1(2), 54-61. https://doi.org/10.35311/jmpm.v1i2.12

Pertiwi, R., Notriawan, D., \& Wibowo, R. H. (2020). Pemanfaatan Tanaman Obat Keluarga (TOGA) Meningkatkan Imunitas Tubuh sebagai Pencegahan Covid-19. Dharma Raflesia: Jurnal Ilmiah Pengembangan Dan Penerapan IPTEKS, 18(2), 110-118. https://doi.org/10.33369/dr.v18i2.12665

Suparmini, \& Wijayanti, A. T. (2015). Masyarakat Desa dan Kota (Tinjauan Geografis, Sosiologis dan Historis). UNY Press.

Wadjdi, M. F., Cahyaning Thias, T. A., Qatrunnada, L., Asga, I. D., Ni'mah, M., Makruf, A., R. Hadiyansa, F., Febriansyah, A. W., Efendi, A., Alfadlilatul Azza, M. W., \& Choiruddin, A. (2020). Pengembangan Jamu Olahan Rumah Tangga Untuk Meningkatkan Perekonomian Masyarakat Melalui Pemasaran E-Commerce. Jurnal Pembelajaran $\begin{array}{lll}\text { Pemberdayaan } \quad \text { Masyarakat } & \text { (JP2M), }\end{array}$ https://doi.org/10.33474/jp2m.v1i2.6506

Wahidah, B. F. (2013). Etnobotani Tumbuhan Obat yang Dimanfaatkan oleh Masyarakat Kecamatan Tompobulu Kabupaten Gowa Sulawesi Selatan [UIN Alauddin]. http://portalriset.uin-alauddin.ac.id/bo/upload/penelitian/publikasi/BAIQ FARHATUL WAHIDAH.pdf

Zayadi, H., Azrianingsih, R., \& Athiroh, N. (2016). Pemanfaatan Hewan Sebagai Obat-Obatan Berdasarkan Persepsi Masyarakat di Kelurahan Dinoyo Malang. Jurnal Kesehatan Islam, 4(1), 1-5. 